\title{
Abundance and temporal distribution of Gonioterma exquisita Duckworth (Lepidoptera, Elachistidae, Stenomatinae) on Byrsonima pachyphylla Griseb. (Malpighiaceae) in the Brazilian Cerrado
}

\author{
Rosevaldo Pessoa-Queiroz ${ }^{1}$, Helena Castanheira de Morais ${ }^{1} \&$ Ivone Rezende Diniz ${ }^{2}$
}

'Pós-graduação em Ecologia, Instituto de Ciências Biológicas, Universidade de Brasília, ICC sul, Térreo, Campus Universitário Darcy Ribeiro, Asa Norte, 70919-970 Brasília-DF, Brasil.rosevaldo.queiroz@gmail.com; morais@unb.br

${ }^{2}$ Departamento de Zoologia, Instituto de Ciências Biológicas, Universidade de Brasília, ICC sul, Térreo, Sala AT-116, Campus Universitário Darcy Ribeiro, Asa Norte, 70910-900 Brasília-DF, Brasil. irdiniz@unb.br

\begin{abstract}
Abundance and temporal distribution of Gonioterma exquisita Duckworth (Lepidoptera, Elachistidae, Stenomatinae) on Byrsonima pachyphylla Griseb. (Malpighiaceae) in the Brazilian Cerrado. The seasonal characteristics of the Cerrado region strongly influence food resource predictability and vegetal tissue nutritional content. The aims of this work were to record the abundance and temporal distribution of Gonioterma exquisita Duckworth, 1964 (Lepidoptera, Elachistidae) and its relation with phenological, physical, and chemical traits of the host plant Byrsonima pachyphylla Griseb. (Malpighiaceae). Four nutritional quality parameters were determined for new and mature leaves: gross protein and nitrogen content, dry matter, and in vitro digestibility. We inspected 200 plants per month, searching for G. exquisita caterpillars. About $35.8 \%$ of the 2,400 plants inspected presented caterpillars, with an abundance peak in the wet season. Caterpillar abundance was positively correlated with mature leaf availability, their food resource. Although mature leaves presented lower gross protein and nitrogen contents than new leaves, this difference was small during the abundance peak of G. exquisita.
\end{abstract}

KEYWORDS. Leaf phenology; mechanical defense; nutritional quality; restricted diet.

RESUMO. Abundância e distribuição temporal de Gonioterma exquisita Duckworth (Lepidoptera, Elachistidae, Stenomatinae) em Byrsonima pachyphylla Griseb. (Malpighiaceae) no Cerrado brasileiro. As características sazonais da região do Cerrado influenciam fortemente a previsibilidade dos recursos alimentares no tempo e no espaço como também a qualidade nutricional dos tecidos vegetais. Os objetivos deste trabalho foram registrar a abundância e a distribuição temporal de Gonioterma exquisita Duckworth, 1964 (Lepidoptera, Elachistidae) e sua relação com aspectos fenológicos, físicos e químicos de sua planta hospedeira, Byrsonima pachyphylla Griseb. (Malpighiaceae). Quatro parâmetros nutricionais foram determinados para folhas novas e maduras: proteína bruta, conteúdo de Nitrogênio, matéria seca e digestibilidade in vitro. Inspecionamos, mensalmente, 200 plantas a procura de lagartas de G. exquisita. Das 2.400 plantas inspecionadas, $35.8 \%$ apresentaram lagartas e seu pico de abundância ocorreu na estação chuvosa. A abundância de lagartas mostrou correlação positiva com a disponibilidade de folhas maduras, seu recurso alimentar. Embora as folhas maduras tenham apresentado taxas menores de proteína bruta e de Nitrogênio que as folhas novas, esta diferença foi muito pequena durante o pico de abundancia de G. exquisita.

PALAVRAS-CHAVE. Defesas mecânicas; dieta restrita; fenologia foliar; qualidade nutricional.

Tropical insects are highly seasonal (Janzen 1993). In Costa Rica, the highest caterpillar abundance occurs during the first three months of the wet season, from May to July (Janzen 1993). In the Brazilian Cerrado, however, this peak happens in the first half of the dry season, which coincidently corresponds to the same months (Morais et al. 1999). Knowledge about seasonal abundance fluctuations of tropical insect populations relies on several studies on adult insects, and usually is restricted to a few species. In general, there is a lack of studies about seasonal activities of immature insects (Morais et al. 1999).

Understanding the composition and diversity of herbivorous insects for individual plant species provides means of investigating the importance of morphological and phenological plant traits on associated fauna (Andrade et al. 1999). Plants attacked mainly by generalist species may be able to escape these herbivores in evolutionary time by evolving chemically novel deterrents, like toxins, to distinguish themselves from other neighboring potential hosts. In contrast, an herbivore fauna consisting mostly of specialists may be much more difficult to evade (Marquis et al. 2002). A specialist insect may have synchrony with plant phenology and be favored by reducing significantly the metabolic costs of its development (Bendicho-López \& Diniz 2004).

The survey of immature lepidopteran in the Brazilian Cerrado began in the 1990s. The caterpillar's low density relative to their food availability and a high incidence of rare species seems to characterize the Cerrado (Price et al. 1995). 
Diniz \& Morais (1997) observed that most lepidopteran species in the Cerrado (74\%) occurred exclusively on a single host plant family, what suggests a high degree of diet specificity. Regarding the caterpillar seasonality in the Cerrado, Morais et al. (1999), working with nine plant species over several years, found that the caterpillar frequency increased in the beginning of the dry season (mid-April), remained high until mid-July and decreased thereafter, reaching smaller numbers in October, the beginning of the wet season in the Cerrado region.

The species considered in this study, Gonioterma exquisita Duckworth, 1964 (Elachistidae), is a small and inconspicuous moth, both in appearance and life style. In the recent classification by Hodges (1999), Stenomatinae (formerly placed in Oecophoridae) was included in a revised and expanded concept of Elachistidae. Diniz et al. (2001) published a list of caterpillars associated with plants in the Brazilian Cerrado, where the Elachistidae figured as the most speciose family (62 species). The genus Gonioterma Walsingham, 1897 is restricted to tropical America (Heppner 1984), and the only references about G. exquisita prior to the 1990 s was its description by Duckworth (1964) and some bionomic data by Travassos-Filho (1972). This species occurs in the Brazilian Cerrado (Diniz et al. 2001), and its caterpillar is narrow and oligophagous, feeds exclusively on pubescent Byrsonyma (Malpighiaceae) leaves, and builds frass and silk planorbid-shaped shelters (Andrade et al. 1999; Diniz et al. 2000).

Gonioterma exquisita occurs on plants of the family Malpighiaceae, which has its origin and distribution center in South America, with $85 \%$ of the species occurring in tropical America (Davis et al. 2002). The genus Byrsonima Rich. is native of the tropics and subtropics with a wide distribution in Central and South America, Mexico, and Florida (Barros 1992). There are 25 species in the Brazilian Cerrado (Ratter et al. 2000) and 10 in the Distrito Federal (Brazil) alone. Byrsonima pachyphylla is one of the host species in the Brazilian Cerrado. Leaf expansion in these plants takes about 50 days and produces pubescent and alkaloid-containing leaves (Marquis et al. 2001). Recently, Cavalcanti \& Ramos (2001) pointed out that Byrsonima crassa Niedenzu and B. pachyphylla Griseb. are synonymous (hereafter this synonym is implied in all references prior to this publication).

The focus of this paper is to investigate the temporal distribution of G. exquisita caterpillars on B. pachyphylla and its possible relationships with leaf phenology of the host plant, including variation in physical and chemical leaf traits through the dry and wet seasons in the Brazilian Cerrado. The hypothesis tested was that in the wet period relatively younger leaves and better nutritional quality of food resources could support a greater number of caterpillars.

\section{MATERIALAND METHODS}

The field site, a cerrado sensu stricto (Goodland 1971) area is located at the University of Brasília Experimental Farm - FAL (Fazenda Água Limpa, 155 ' ' S, 47 $55^{\circ} \mathrm{W}$ ), Distrito Federal, Brazil, at 1,100 $\mathrm{m}$ in elevation. The Cerrado region has a sharp seasonal climate: a dry season from May to September and a wet season from October to April. Detailed information about FAL vegetation can be found in Ratter (1991). The climate data of the field work period were provided by the Meteorological Station of the Ecological Reserve, Serra do Roncador - RECOR/IBGE in Brasília, DF (1556’41"S, $47^{\circ} 53^{\prime} 07^{\prime \prime} \mathrm{W}$; 1,100 $\mathrm{m}$ in elevation), contiguous to FAL.

The work was carried out from October 2001 to September 2002. Every month, 200 different individuals of B. pachyphylla from 0.5 to $2 \mathrm{~m}$ in height were inspected. For all plants, we carefully recorded number and size of G. exquisita caterpillars, leaf phenological stage, and presence of flowers and fruits. Some caterpillars were collected and reared under laboratory conditions. The species was identified by Dr. Vitor O. Becker. Voucher specimens are deposited in the Entomological Collection of the Zoology Department at the University of Brasília.

The relative size of caterpillars in the field was inferred based on the shelter cover diameter (Fig. 1A; 1B) and classified into three categories: small - S (1 cm or less); medium - M (from 1.1 to $2 \mathrm{~cm}$ ) and large - L (up to $2 \mathrm{~cm}$ ). Leaves were characterized according to their relative age using the following categories: 1) new leaves $(\mathrm{N})$ - expanding or recently expanded leaves still flexible and covered with trichomes on both surfaces (Fig. 2A); 2) mature leaves (M) - fully expanded leaves, inflexible and partially covered with trichomes or glabrous leaves (Fig. 2B); and 3) old leaves (O) glabrous yellowish, or dry leaves still attached to the plant (Fig. 2C). The abaxial surface of new and mature leaves was pubescent (Fig. 2D). Leaf characteristics were evaluated monthly on 10 plants by collecting one new and one mature undamaged leaf from each plant (totaling 120 new and 120 mature leaves in the one year period). Trichome density (\% of covered area) was estimated from three $1 \mathrm{~cm}^{2}$ patches on both sides of each leaf. Water content (WC) and the specific leaf weight (SLW) of these leaves were estimated by first weighing fresh leaves that had been kept on ice and weighing them again after drying for $72 \mathrm{~h}$ at $65^{\circ} \mathrm{C}$, when the mass stabilized.

Leaf nutritional quality was measured four times in 2002 in the Analytical Chemistry Laboratory of EMBRAPA Cerrados in Brasília: April (transition from wet to dry season); July (dry season); September (transition from dry to wet season) and December (wet season). Total nitrogen (N), in vitro digestibility (IVD), gross protein (GP) and dry matter (DM) were determined. One new and one mature undamaged leaves were collected from 10 plants (totaling 10 new and 10 mature leaves in each period). The leaves were dried for 72 hours at $65^{\circ} \mathrm{C}$, and then pulverized for the analysis.

We used the Mann-Whitney test with a significance level of 0.05 to evaluate differences in physical characteristics of the host plant. Spearman correlation was used to verify the relationship between $G$. exquisita abundance and food resource (mature leaves) availability of the host plant (Fig. 2E). All statistical analyses were conducted using BioEstat 2.0 (Ayres et al. 2000). 

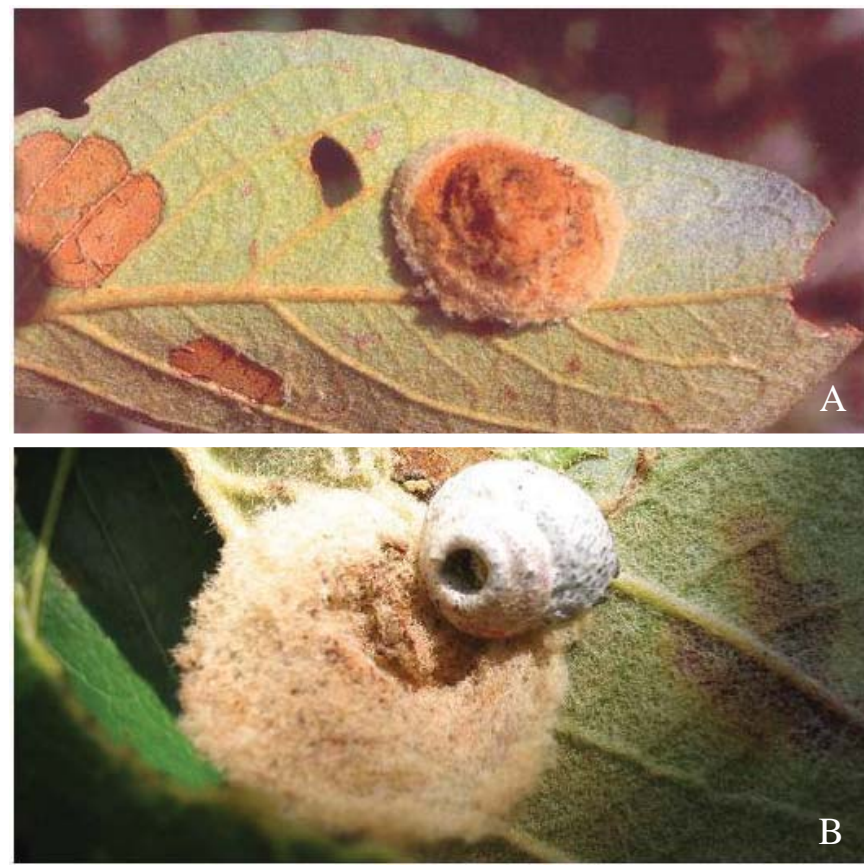

Fig. 1. A, Shelter of Gonioterma exquisita covered with Byrsonima leaf trichomes; B, Shelter cover partially removed.

\section{RESULTS}

Overall we examined 2,400 plants, 461 of which presented 1,744 live caterpillars and 760 dead caterpillars or empty shelters of G. exquisita. Forty-five caterpillars in diapause were observed on the surrounding herbaceous vegetation (not included in the number of live caterpillars). We also found 1,087 caterpillars of 39 species. Thus $G$. exquisita was the most common lepidopteran species associated with $B$. pachyphylla and its occurrence (expressed as the number of plants with caterpillars) and abundance (absolute number of caterpillars) increased in January and remained high until March, during the second half of the wet season, and then declined sharply (Tab.I).

The abundance of G. exquisita showed no significant correlation with local average annual rainfall. The host plant produces leaves all year round with peaks from September through November (Tab.I). The abundance of G. exquisita caterpillars was associated with leaf phenology (Tab.I). It was positively correlated with availability of mature leaves $\left(\mathrm{R}_{\text {Spearman }}=0.8613 ; \mathrm{p}=0.0003\right)$ and negatively correlated with availability of new leaves $\left(R_{\text {Spearman }}=-0.598 ; p=0.0399\right)$. There was no correlation with old leaves. Even though leaves of all relative ages were available throughout the year, mature leaves were the most abundant and lasting resource of B. pachyphylla (Tab. I).

The average leaf adaxial pubescence was significantly different $(\mathrm{p}=0.0009)$ between seasons only for new leaves (Tab. II), whereas leaf abaxial pubescence (Fig. 2D) showed no significant variation with leaf age or season. Specific leaf weight (SLW) varied significantly between seasons for mature
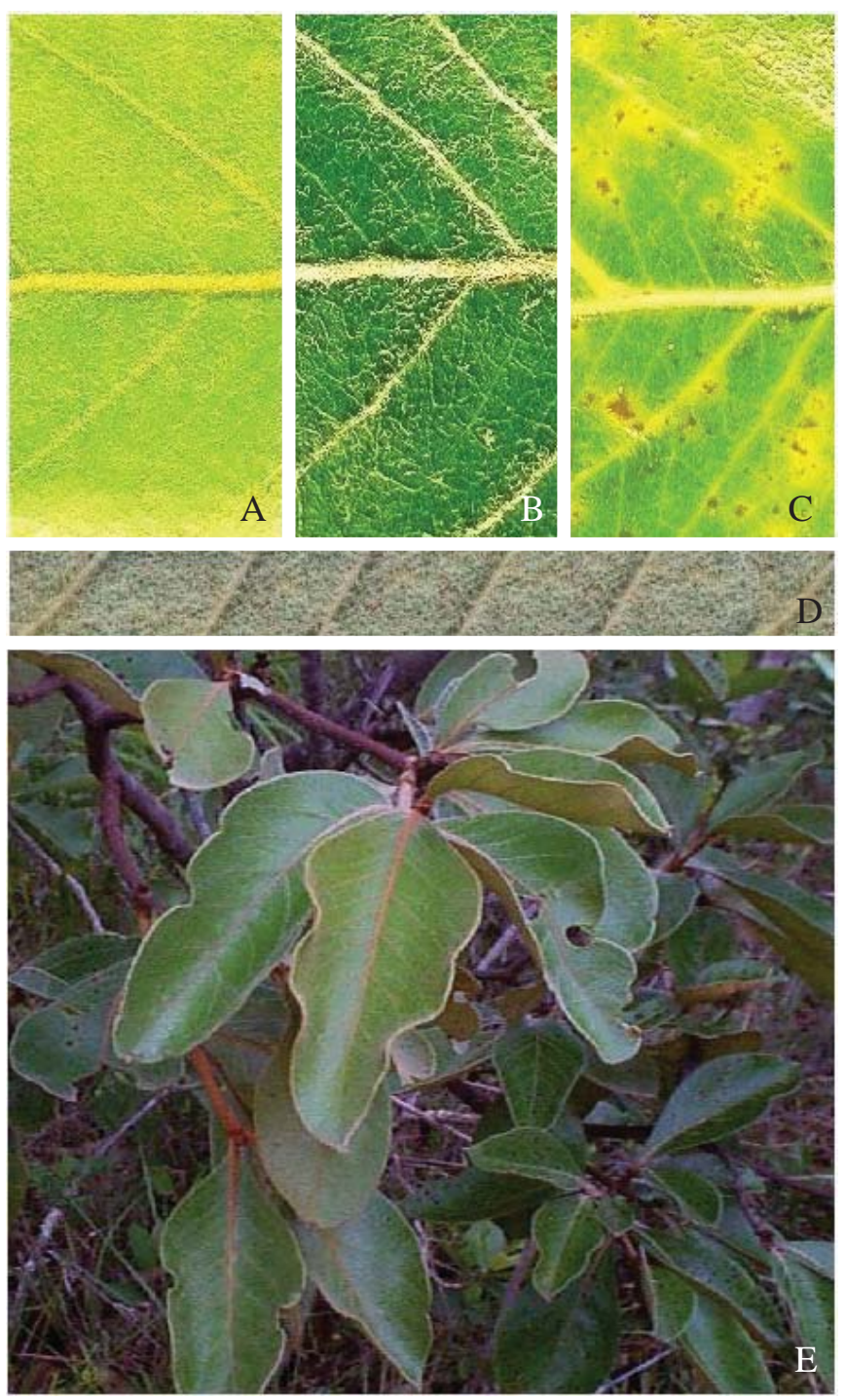

Fig. 2. Byrsonima pachyphylla leaf aspect across relative ages. A, new; $\mathrm{B}$, mature; C, old; 2, abaxial surface; E, general view of the plant.

leaves $(\mathrm{p}=0.0378)$ but not for new ones $(\mathrm{p}=0.2965)$. From January through March and in May and July there were no significant differences between relative leaf ages. There was no correlation between SLW and G. exquisita abundance. Water content varied significantly between seasons for new leaves $(\mathrm{p}=0.0097)$ but not for mature leaves $(\mathrm{p}=0.2461)$ (Tab. II). Only in January, February, and July there were no significant differences in water content between relative leaf age. There was no correlation between mean water content and $G$. exquisita abundance.

The in vitro digestibility of mature leaves was greater than for new leaves, but this difference decreased during the dry/ wet season transition. Gross protein and nitrogen content of mature leaves were lower than in new ones, but little difference was observed in the wet season. The dry matter did not vary with relative leaf age or season (Tab. III). 
Table I. Month occurrence and abundance of Gonioterma exquisita caterpillars in Byrsonima pachyphylla and its leaf phenology.

\begin{tabular}{lccccc}
\hline $\begin{array}{c}\text { Month/ } \\
\text { Year }\end{array}$ & $\begin{array}{c}\mathrm{N}^{\circ} \begin{array}{c}\text { plants } \\
\text { with } \\
\text { caterpillars }\end{array} \\
\text { caterpillars }\end{array}$ & $\begin{array}{c}\mathrm{N}^{\mathrm{o}} \\
\text { leaves }\end{array}$ & $\begin{array}{c}\text { \% new } \\
\text { leaves }\end{array}$ & $\begin{array}{c}\text { \% old } \\
\text { leaves }\end{array}$ \\
\hline Wet season & & & & & \\
Oct/01 & 0 & 0 & 49.63 & 46.98 & 3.40 \\
Nov/01 & 0 & 0 & 60.65 & 37.25 & 2.10 \\
Dec/01 & 02 & 07 & 72.25 & 27.20 & 0.55 \\
Jan/02 & 105 & 488 & 82.80 & 17.20 & 0.00 \\
Feb/02 & 137 & 716 & 86.55 & 7.75 & 5.70 \\
Mar/02 & 99 & 345 & 82.55 & 7.65 & 9.80 \\
Apr/02 & 35 & 59 & 83.40 & 11.35 & 5.25 \\
\hline Dry season & 40 & 62 & 79.20 & 13.00 & 7.80 \\
May/02 & 49 & 42 & 83.00 & 5.85 & 11.15 \\
Jun/02 & 24 & 25 & 71.85 & 4.10 & 24.05 \\
Jul/02 & 19 & 0 & 48.60 & 14.35 & 37.05 \\
Aug/02 & 0 & 0 & 32.35 & 42.40 & 25.25 \\
Sep/02 & 0 & 1.744 & 69.40 & 19.59 & 11.01 \\
\hline Total & 461 & & & & \\
\hline
\end{tabular}

\section{DISCUSSION}

The overall attack of plants by G. exquisita caterpillars (19.21\%) differed from the attack pattern noted for Cerrado plants from previous studies (§10\%) (Diniz \& Morais 1997; Bendicho-López \& Diniz 2004). Caterpillar occurrence and abundance in B. pachyphylla was higher during the second half of the wet season, contrasting with the general pattern for the Cerrado, an abundance peak of caterpillars from may to July (dry season), reported by Morais et al. (1999) for 137 lepidopteran species. Janzen (1993) found that most of the lepidopteran species in Santa Rosa National Park in Costa Rica showed a seasonality similar to G. exquisita in the Brazilian Cerrado: low caterpillar abundance at the beginning of the wet season (October to December).

Many possible explanations could be used to account for monthly abundance variation. Low caterpillar abundance in the first three months of the wet season might be due to: 1) delay in oviposition; 2) time required for eggs to hatch (Janzen 1993); and 3) temporary monopolization of food resources by G. exquisita consuming B. pachyphylla leaves with higher nutritional quality and digestibility (Tab. III) during peak abundance. It could reduce the permanence time of caterpillars on the plant, as well as the need for switching to another host plant, reducing the chance of predator and parasitoid attacks. Jones et al. (2002) stated that shelter-building caterpillars are generally palatable. Conspicuous caterpillars may provide not only visual cues to natural enemies but chemical as well, by causing plants to release volatile compounds in response to the herbivory. Thus, the presence of other caterpillar species can make G. exquisita more vulnerable.

Larval development of G. exquisita seems to be repressed by leaf deciduity peak (August-September) and new leaf production peak (September-November) (Tab. I). The reduction in availability and nutritional quality of mature leaves can also hamper larval development (Tab. III). It is worth to remember that during this critical period the environmental conditions change from the drought stress to heavy rains. The low abundance of caterpillars at the beginning of the wet season (October-November) could be an escape strategy from predators and parasitoids, more numerous just after the first rains (Morais et al. 1999).

The trichomes are generally considered to be mechanical and chemical barriers to herbivory (Paleari \& Santos 1998; Ribeiro \& Fernandes 2000). Nevertheless, the perennial trichome abaxial cover of $B$. pachyphylla suggests the preference of G. exquisita for the host plant, it makes a shelter cover with trichomes and silk (Diniz et al. 2000). In B. intermedia Juss., whose leaf pubescence is reduced as compared to $B$. pachyphylla, G. exquisita utilizes silk and frass to make a shelter cover (Travassos-Filho 1972).

The results of SLW showed a high sclerophylly in both new and mature leaves' relative ages of B. pachyphylla, which is characteristic of evergreen species (Leoni 1997), although this is a deciduous species. Leaf deciduity, common in the Cerrado, represents a vegetative adaptation against water loss and nutritional deficit. Nutrient retranslocation, mainly of nitrogen and potassium (Oki 2000), could explain the oscillation of nitrogen content in our samples (Tab. III). Larcher (2000) suggested that the decrease of nitrogen content may be related to water stress. Plant tissues generally contain low concentrations of nitrogen with an average of $2.14 \%(n=400$ plant species) (Auebach \& Strong 1981). In Cerrado plants, this percentage is even lower (Marquis et al. 2001). The in vitro digestibility may be associated with the oscillation of tannin rates. Oki (2000) found that the production of tannin varies seasonally in $B$. intermedia. Caterpillar preference for mature leaves can be tentatively explained by a combination

Table II. Leaf physical characteristics of Byrsonima pachyphylla within and between seasons. Data are presented as mean \pm SD (Standard deviation). SLW=specific leaf weight and $\mathrm{WC}=$ water content.

\begin{tabular}{lccccccc}
\hline \multirow{2}{*}{ Season } & \multicolumn{3}{c}{ New leaves } & & \multicolumn{3}{c}{ New leaves } \\
\cline { 2 - 3 } & $\begin{array}{c}\text { SLW } \\
\left(\mathrm{mg} / \mathrm{cm}^{2}\right)\end{array}$ & WC $(\%)$ & $\begin{array}{c}\text { adaxial } \\
\text { pubescence }(\%)\end{array}$ & & $\begin{array}{c}\text { SLW } \\
\left(\mathrm{mg} / \mathrm{cm}^{2}\right)\end{array}$ & WC $(\%)$ & $\begin{array}{c}\text { adaxial } \\
\text { pubescence }(\%)\end{array}$ \\
\hline Wet (Oct-Apr) & $14,89 \pm 2,58$ & $54,07 \pm 5,57$ & $65,11 \pm 24,86$ & & $17,26 \pm 2,40$ & $49,36 \pm 4,10$ & $1,53 \pm 3,99$ \\
Dry (May-Sep) & $14,38 \pm 2,66$ & $56,43 \pm 7,97$ & $74,47 \pm 18,04$ & & $16,66 \pm 2,56$ & $50,00 \pm 4,42$ & $0,51 \pm 2,15$ \\
\hline
\end{tabular}


Table III. Leaf chemical characteristics of Byrsonima pachyphylla throughout the year of 2002. IVD= in vitro digestibility; N= Nitrogen content; $\mathrm{GP}=$ gross protein and $\mathrm{DM}=$ dry matter.

\begin{tabular}{|c|c|c|c|c|c|c|c|c|}
\hline \multirow[t]{2}{*}{ Analysis (\%) } & \multicolumn{2}{|c|}{$\begin{array}{c}\text { April } \\
\text { (wet/dry) }\end{array}$} & \multicolumn{2}{|c|}{$\begin{array}{l}\text { July } \\
\text { (dry) }\end{array}$} & \multicolumn{2}{|c|}{$\begin{array}{c}\text { September } \\
\text { (dry/wet) }\end{array}$} & \multicolumn{2}{|c|}{$\begin{array}{c}\text { December } \\
\text { (wet) }\end{array}$} \\
\hline & New & Mature & New & Mature & New & Mature & New & Mature \\
\hline IVD & 15.85 & 24.47 & 22.48 & 29.74 & 14.17 & 19.03 & 12.01 & 20.04 \\
\hline $\mathrm{N}$ & 1.98 & 0.89 & 0.78 & 0.67 & 1.45 & 0.87 & 1.51 & 1.41 \\
\hline GP & 12.76 & 5.75 & 5.00 & 4.34 & 9.00 & 6.00 & 10.00 & 9.00 \\
\hline DM & 96.91 & 96.94 & 96.44 & 96.47 & 97.48 & 97.83 & 96.31 & 97.71 \\
\hline
\end{tabular}

of small differences in nitrogen and gross protein contents in the wet season associated with the higher digestibility.

Some studies indicate that food resources are available in high quantities to folivorous insects in the Cerrado, but this is not reflected by a higher insect abundance (Morais et al. 1995). Thus the community structure is not based on competitive relationships and factors such as abiotic seasonality, predators, parasitoids, and leaf nutritional quality may be more important in shaping the community. In fact, Begon \& Mortimer (1993) stated that local species diversity is directly related to predator efficiency to prevent the monopolization of the main environmental resource by a single species. Since mature leaves are the most abundant and predictable resource in $B$. pachyphylla, it is expected that G. exquisita be restricted to them. The cryptic behavioral array of $G$. exquisita and its relationship with the host plant could account for the dominance of this species in the study system. Gonioterma exquisita was sponged in all instars and there was a massive predation in the last instar. This species is able to reproduce and keep its abundance most likely because of its ability to overcome adverse conditions (predators, parasitoids, climate, and low leaf nutritional quality) and diapause, while other species, with less restricted diets, forage lower nutritional quality leaves in the same host plant.

There is a conjunction of factors that probably support a great number and a high rate of survival G. exquisita caterpillars on mature leaves of B. pachyphylla: higher leaf digestibility; greater duration of this leaf stage, its higher proportion throughout the year, and its high leaf specific weight. One of the strategies that could allow G. exquisita high abundance in the wet season is the facultative diapause across the dry season. At last, the occurrence of another species of the same genus, G. indecora (Zeller, 1854), on the same host plant and with similar caterpillars characteristics supports the hypothesis of temporal resource sharing by these two congeneric species.

Acknowledgements. We would like to thank Dr. Vitor O. Becker, who identified the moth. Dr. Sérgio Folle and Dr. Thelma Saueressig (EMBRAPA Cerrados), for leaf nutritional quality analysis. Dr. Mundayatan Haridasan (Universidade de Brasília) who made suggestions and corrections in the manuscript. CNPq provided a scholarship for the first author.

\section{REFERENCES}

Andrade, I.; H. C. Morais; I. R. Diniz \& C. Van den Berg. 1999. Richness and abundance of caterpillars on Byrsonima (Malpighiaceae) species in an area of cerrado vegetation in Central Brazil. Revista de Biología Tropical 47: 691-695.

Auebach, M. J. \& D. R. Strong. 1981. Nutritional ecology of Heliconia herbivores: experiments with plant fertilization and alternative hosts. Ecological Monographs 5: 63-83.

Ayres, M.; M. Ayres Jr.; D. L. Ayres \& A. S. Santos. 2000. BioEstat 2.0: aplicações estatísticas nas áreas de ciências biológicas e médicas. Sociedade Civil Mamirauá, Belém, PA. 272 p.

Barros, M. A. G. 1992. Fenologia da floração, estratégias reprodutivas e polinização de espécies simpátricas do gênero Byrsonima Rich. (Malpighiaceae). Revista Brasileira de Biologia 52: 343-353.

Begon, M. \& M. Mortimer. 1993. Population Ecology. $2^{\text {nd }}$ ed. Blackwell Scientific Publications. 220 p.

Bendicho-López, A. \& I. R. Diniz. 2004. Life history and immature stages of Chlamydastis platyspora (Elachistidae). Journal of Lepidopterists' Society 58: 75-79.

Cavalcanti, T. B. \& A. E. Ramos. 2001. Flora do Distrito Federal. Vol. 1. Brasília, EMBRAPA, Recursos Genéticos e Biotecnologia. $359 \mathrm{p}$.

Davis, C. C.; C. D. Bell; S. Mathews \& M. J. Donoghue. 2002. Laurasian migration explains Gondwanan disjunctions: evidence from Malpighiaceae. Proceedings of the National Academy of Sciences of U.S.A. 99: 6833-6837.

Diniz, I. R. \& H. C. Morais. 1997. Lepidopteran caterpillar fauna of cerrado host plants. Biodiversity and Conservation 6: $817-$ 836.

Diniz, I. R.; H. C. Morais \& J. D. Hay. 2000. Natural history of herbivores feeding on Byrsonima species. Brazilian Journal of Ecology 1, 2: 49-54.

Diniz, I. R.; H. C. Morais \& A. J. A. Camargo. 2001. Host plants of lepidopteran caterpillars in the cerrado of the Distrito Federal, Brazil. Revista Brasileira de Entomologia 45: 107-122.

Duckworth, W. D. 1964. A new Brazilian moth of the genus Gonioterma with notes on related species (Lepidoptera: Stenomidae). Proceedings of the United States National Museum 115: 381-390.

Goodland, R. 1971. A physionomic analysis of the "cerrado" vegetation of central Brazil. Journal of Ecology 59: 411-419.

Heppner, J. B. 1984. Atlas of Neotropical Lepidoptera checklist, Micropterigoidea-Immoidea. Part.I ed. W. Gunk Publishers. $112 \mathrm{p}$.

Hodges, R. W. 1999. The Gelechioidea. p. 132-158. In: N. P. Kristensen (ed.). Lepidoptera, moths and butterflies. Vol. 1: Evolution, Systematics and Biogeography. Berlin \& New York, Walter de Guvter. X + 491 p.

Janzen, D. H. 1993. Caterpillar seasonality in a costa rican dry forest. p. 448-477. In: Caterpillars: ecological and evolutionary constraints on foraging. Stamp, N. E. \& Casey, T. M. (eds). Chapmann \& Hall. 584 p. 
Jones, M. T.; I. Castellanos \& M. R. Weiss. 2002. Do leaf shelters always protect caterpillars from invertebrate predators? Ecological Entomology 27: 753-757.

Larcher, W. 2000. Ecofisiologia vegetal. Carlos H. B. A. Prado (Trad.). Artes e Textos, São Carlos, SP. 531 p.

Leoni, E. V. 1997. Relação de herbivoria com teores de taninos, nitrogênio, água e peso específico foliar em duas espécies da família Malpighiaceae, em um Cerrado do Município de São Carlos, SP. Dissertação de mestrado do Programa em Ecologia e Recursos Naturais da Universidade Federal de São Carlos. 73 p.

Marquis, R. J.; I. R. Diniz \& H. C. Morais. 2001. Patterns and correlates of interspecific variation in foliar insect herbivory and pathogen attack in Brazilian cerrado. Journal of Tropical Ecology 17: $127-148$.

Marquis, R. J.; H. C. Morais \& I. R. Diniz. 2002. Interactions among Cerrado plants and their herbivores: unique or typical. p. 306-328. In: The Cerrados of Brazil - Ecology and Natural History of a Neotropical Savanna. Oliveira, P. S. \& Marquis, R. J. (eds). Columbia University Press. 424 p.

Morais, H. C.; I. R. Diniz \& L. Baumgarten. 1995. Padrões de produção de folhas e sua utilização por larvas de lepidópteros em um cerrado de Brasília. Revista Brasileira de Botânica 18: 163-170.

Morais, H. C; I. R. Diniz \& D. M. S. Silva. 1999. Caterpillar seasonality in a central Brazilian cerrado. Revista de Biología Tropical 47: $1025-1033$.
Oki, Y. 2000. Herbivoria por lepidópteros em Byrsonima intermedia Juss. (Malpighiaceae) na ARIE Pé-de-Gigante, Santa Rita do Passa Quatro SP. Dissertação de Mestrado, Programa de PósGraduação em Entomologia, Universidade de São Paulo. 137 p.

Paleari, L. M. \& F. A. M. Santos. 1998. Papel do indumento piloso na proteção contra a herbivoria em Miconia albicans (Melastomataceae). Revista Brasileira de Biologia 58: 151-157.

Price, P. W.; I. R. Diniz; H. C. Morais \& E. S. A. Marques. 1995. The abundance of insect herbivores species in the tropics: the high local richness of rare species. Biotropica 27: 468-478.

Ratter, J. A. 1991. Notas sobre a vegetação da Fazenda Água Limpa (Brasília, DF). Textos universitários $n^{\circ} 3$, Ed. UnB, Brasília, DF. 136 p.

Ratter, J. A.; S. Bridgewater; J. F. Ribeiro; T. A. B. Dias \& M. R. Silva. 2000. Estudo preliminar da distribuição das espécies lenhosas da fitofisionomia cerrado sentido restrito nos estados compreendidos pelo bioma cerrado. Boletim do Herbário Ezechias Paulo Heringer 5: 5-43.

Ribeiro, S. P. \& G. W. Fernandes. 2000. Interações entre insetos e plantas no cerrado: teoria e hipóteses de trabalho. p. 299-320. In: Martins, R. P.; Lewinsohn, T. M. \& Barbeitos, M. S. (eds.). Ecologia e comportamento de Insetos. Série Oecologia Brasiliensis, Vol. VIII. PPGE-UFRJ. Rio de Janeiro, Brasil. 435 p.

Travassos-Filho, L. P. 1972. Dados bionômicos de Gonioterma chlorina e de G. exquisita (Lepidoptera, Stenomidae). Studia Entomologica 15: 485-496. 